\title{
5' Flanking Sequences of the Rat Tyrosine Hydroxylase Gene Target Accurate Tissue-Specific, Developmental, and Transsynaptic Expression in Transgenic Mice
}

\author{
Shilpi A. Banerjee, ${ }^{1}$ Peter Hoppe, ${ }^{3}$ Murray Brilliant, ${ }^{3, a}$ and Dona M. Chikaraishi ${ }^{2}$ \\ 'Department of Microbiology and Molecular Biology and ${ }^{2}$ Neuroscience Program, Tufts University School of Medicine, \\ Boston, Massachusetts 02111 and 3Jackson Laboratory, Bar Harbor, Maine 04609
}

Transgenic mice were generated in which sequences that flank the rat tyrosine hydroxylase (TH) gene were linked to the bacterial chloramphenicol acetyl transferase (CAT) gene. Mice bearing 4.8 kilobases (kb) of $5^{\prime}$ flanking DNA exhibited correct tissue-specific expression in the CNS and periphery. Expression was more robust in the CNS than in the periphery, although CAT activity was clearly detected in sympathetic ganglia (superior cervical ganglia) and the adrenal, the two peripheral tissues that contain TH-positive cells. Within the brain, CAT expression was seen in all the expected areas containing TH-positive cell bodies, with little or no expression in other regions.

In the olfactory bulb, which contains the majority of the CNS TH cells, developmental expression of CAT was quantifiable and was found to parallel the postnatal rise in endogenous TH, with both TH and CAT reaching adult levels by postnatal day 21 . Since TH activity in the olfactory bulb requires afferent input, the dependence of CAT activity on transsynaptic input was also assayed in transgenic mice. Like the endogenous TH activity, CAT levels were also reduced by deafferentation, in parallel with loss in endogenous dopamine levels.

While previous experiments demonstrated that shorter $5^{\prime}$ flanking regions ( $2.5 \mathrm{~kb}$ and $3.5 \mathrm{~kb}$ of $5^{\prime}$ upstream sequences of the human and mouse TH gene, respectively) failed to direct accurate tissue-specific expression, our data demonstrate that $4.8 \mathrm{~kb}$ of $5^{\prime}$ flanking sequence of the rat TH gene contains sufficient regulatory information to mediate appropriate tissue-specific expression in all CNS and PNS tissues, as well as to mediate developmental and transsynaptic expression in the olfactory bulb.

Expression of tyrosine hydroxylase (TH), the first and rate-limiting enzyme of catecholamine neurotransmitter biosynthesis, is limited to discrete sets of cells in the CNS and PNS. TH

\footnotetext{
Received Mar. 10, 1992; revised June 9, 1992; accepted June 10, 1992.

This work was supported by NIH Grants NS 22675 and NS 29679 to D.M.C, and NIDDK P30 DK34938. We thank Dr. S. Roffler-Tarlov for performing the brain dissections and critically reading the manuscript, Dr. M. Schwartz-Levey for help with the deafferentation experiments, and Dr. D. Hunter for critically reading the manuscript.

Correspondence should be addressed to Dona M. Chikaraishi, Ph.D., Program in Neuroscience, 136 Harrison Avenue, Tufts University School of Medicine, Boston, MA 02111 .

${ }^{2}$ Present address: Institute for Cancer Research, Fox Chase Cancer Center, 7701 Burholme Street, Philadelphia, PA 19111.
}

Copyright $(1992$ Society for Neuroscience $0270-6474 / 92 / 124460-08 \$ 05.00 / 0$ neurons of the CNS include the adrenergic and noradrenergic cells in the brainstem, dopaminergic cells of the midbrain and diencephalon (periventricular and hypothalamic nuclei), and the retinal amacrine cells and the dopaminergic cells in the olfactory bulb (OB). In the periphery, TH expression is largely limited to sympathetic ganglia and the adrenal medullary chromaffin cells. These peripheral TH cells are closely related: they derive from a common precursor that originates in the neural crest (Anderson and Axel, 1986; Anderson et al., 1991), and chromaffin cells from neonates can be transdifferentiated into cells that resemble sympathetic neurons by NGF (Aloe and Levi-Montalcini, 1979; Naujoks et al., 1982; Doupe et al., 1985). In contrast, CNS TH neurons arise from independent cell groups during neurogenesis, express $\mathrm{TH}$ at different times, and are functionally and anatomically distinct (Specht et al., 1981a; Bjorklund and Lindvall, 1984). The mechanism responsible for TH expression in such disparate cell groups might be expected to rely on multiple regulatory elements, some that may be needed in all TH tissues and others that may mediate expression in a particular cell group. As a first step in defining elements that direct cell-specific expression of $\mathrm{TH}$, we sought to identify those DNA regions flanking the rat $\mathrm{TH}$ gene that mediate correct expression in all the appropriate TH cell groups.

Previous studies aimed at defining cis-acting DNA elements that direct TH expression have been of two sorts: those performed in vitro in cultured cells and those performed in vivo in transgenic mice. The in vitro work from our laboratory compared expression of a chloramphenicol acetyl transferase (CAT) reporter gene under the transcriptional control of $5^{\prime}$ flanking TH DNA in a TH-expressing pheochromocytoma (PC) cell line with that in a variety of non-TH-expressing lines. These experiments demonstrated that 212 base pairs (bp) of DNA upstream of the transcription start site were sufficient for TH transcription in PC cells and that sequences between -212 and -187 (where +1 is the start of transcription) were required (Cambi et al., 1989; Fung et al., 1992). Further experiments using site-directed mutagenesis to pinpoint functional elements demonstrated that two sites known to bind transcription factors work together to direct appropriate expression in cultured cells (Yoon and Chikaraishi, 1992). One site is an API element (TGATTCA) at -205 that is bound by members of the FosJun family of transcription factors (Curran and Franza, 1988); the other contains an E-box motif (CAXXTG) at -194 that interacts with transcription factors containing a helix-loop-helix motif like myc, MyoD, the products of achaete-scute, and $\mathrm{E} 2 \mathrm{~A}$ (Murre et al., 1989; Blackwell and Weintraub, 1990). While 
these experiments provide fine resolution mapping of sites important for transcription in adrenal medullary PC cells, they give no information about tissue-specific expression in the neurons of the CNS or in sympathetic neurons, that is, in true neurons. In addition, the PC lines represent a limited range of developmental stages that may not reflect the mature state of differentiation. Due to the paucity of TH-expressing CNS cell lines, investigations of $\mathrm{TH}$ regulation in the CNS have used transgenic mice, where fine mapping is very difficult due to the time and expense involved in maintaining transgenic lines.

Although limited in number, previous experiments in which $\mathrm{TH}$ regulatory regions were used in transgenic mice have failed to demonstrate correct tissue-specific expression, although some TH cell groups were appropriately targeted. In a recent study, the human TH gene, including the entire coding sequence, 2.5 kilobases $(\mathrm{kb})$ of $5^{\prime}$ flanking region, and $0.5 \mathrm{~kb}$ of $3^{\prime}$ flanking region, was expressed in transgenic mice (Kaneda et al., 1991). The transgene was expressed in the brain and the adrenal, both TH-expressing tissues. However, primer extension analysis performed on RNA from various brain regions revealed inappropriate expression of human $\mathrm{TH}$ message in regions that lack TH-positive cell bodies; these regions included the frontal cortex, striatum, and the hippocampus. In fact, expression in the inappropriate areas appeared at least as strong as expression in $\mathrm{TH}$-positive areas. Unfortunately, this study did not examine expression in the sympathetic ganglia or in the main OB. In our laboratory, $2.8 \mathrm{~kb}$ of $5^{\prime}$ flanking rat $\mathrm{TH}$ sequences directed reporter gene expression to the adrenal chromaffin cells and to CNS midbrain neurons, but not to sympathetic ganglia or the $\mathrm{OB}$. In addition, expression was observed in non-TH-expressing cells in the CNS (Suri and Chikaraishi, 1991; S. A. Banerjee and D. M. Chikaraishi, unpublished observations). Similar results were obtained by Morgan and Sharp using sequences from the mouse $\mathrm{TH}$ gene linked to $\beta$-galactosidase. They reported that transgenic mice carrying $3.5 \mathrm{~kb}$ of $5^{\prime}$ flanking DNA demonstrated appropriate $\beta$-galactosidase expression in the brainstem, midbrain, and adrenal, but ectopic reporter expression in other CNS regions, which may have been due to the site of integration (Morgan and Sharp, 1991; W. Morgan, personal communication). Taken together, these studies indicate that none of the transgenic lineages so far examined have demonstrated completely correct tissue-specific expression. In all cases, some appropriate TH-positive cell groups do express the linked reporter, while others do not; in addition, ectopic CNS expression was observed in all three studies.

Therefore, this study was undertaken to determine if the full repertoire of $\mathrm{TH}$-expressing cells could be appropriately targeted by $5^{\prime}$ flanking sequences from the rat gene. More importantly, we wanted to assess whether regulatory sequences that confer correct tissue-specific expression could also mediate response to developmental and transsynaptic cues. These studies were performed in the $\mathrm{OB}$, which contains the majority of $\mathrm{TH}$ neurons in the CNS and hence would be expected to provide the strongest reporter expression. In addition, while TH is first observed at embryonic day 14.5 (E14.5) in most TH-expressing CNS neurons, its onset in the $\mathrm{OB}$ is postnatal, climinating the need to dissect separate catecholaminergic loci cleanly from embryonic brain (Specht et al., 1981a; McLean and Shipley, 1988). Furthermore, the OB provides the best CNS model for transsynaptic regulation of $\mathrm{TH}$, since deafferentation has been shown to reduce TH protein and RNA dramatically (Baker et al., 1988; Ehrlich et al., 1990). Hence, we also assessed the ability of the TH sequences to regulate physiologically relevant induction during development and in response to afferent innervation.

\section{Materials and Methods}

The plasmid -4.8 THCAT has been previously described (Cambi et al. 1989). In order to eliminate plasmid sequences from the injected DNA, -4.8 THCAT plasmid DNA was partially digested downstream from the SV40 polyA site at bp 1923 with Apal (Fig. 1) and at either the unique HindIII site immediately preceding the TH DNA (to generate the -4.8 THCAT lineages) or the SstI site at $b p-272$ (to generate the -272 THCAT lineages). The appropriate fragment was gel purified and injected into fertilized B $6 \times \mathrm{LT} / \mathrm{Sv}$ F1 eggs. Transgene-positive animals were identified by dot blots or Southern blots of DNA obtained from tail biopsies. The radioactive probe used was generated by random primed synthesis from the plasmid pucCAT. Subsequent transgenic progeny were bred with B6D2 F1 hybrid animals (Taconic) to maintain transgenic lines.

CAT assays. Tissues were excised and quickly frozen on dry ice and stored at $-70^{\circ} \mathrm{C}$ until further use. Tissue extracts were made by homogenization in $250 \mathrm{~mm}$ Tris, $1 \mathrm{~mm}$ EDTA, pH 7.6. These were heated at $65^{\circ} \mathrm{C}$ for $5 \mathrm{~min}$ to inactivate deacetylases (Mercola et al., 1985). The insoluble fraction was removed by centrifugation, and the supernatant was used in the assay. Assays were performed in a $180 \mu \mathrm{l}$ volume containing final concentration of $3.3 \mathrm{~mm}$ acetyl coenzyme A (Pharmacia) and $0.5 \mu \mathrm{Ci}$ of ${ }^{14} \mathrm{C}$-chloramphenicol (New England Nuclear; 54.9 $\mathrm{mCi} / \mathrm{mol}$ ), $250 \mathrm{~mm}$ Tris, and $1 \mathrm{~mm}$ EDTA. Reactions were incubated overnight at $37^{\circ} \mathrm{C}$ and then extracted with ethyl acetate. Thin-layer chromatography and autoradiography were performed on these samples to separate and visualize the acetylated and unacetylated forms of chloramphenicol. The spots corresponding to each form on the thin-layer chromatography plate were counted in a scintillation counter in order to determine the percentage conversion of chloramphenicol to its acetylated forms. Protein assays were performed using the MicroBCA reagent (Pierce). For brain, liver, heart, kidney, and spleen, $60 \mu \mathrm{g}$ of protein was used in each assay. For superior cervical ganglion (scg) and adrenals, up to six organs were pooled for each assay; that is, approximately 200 $300 \mu \mathrm{g}$ of protein was used in each assay. The olfactory bulb determinations were carried out on single bulbs.

Dopamine assays. Dopamine from bulbs was analyzed by HPLC followed by electrochemical detection (HPLC-ECD) as previously described (Kawano and Margolis, 1982), with modifications. Briefly, OBs from the killed animals were excised and immediately homogenized in $200 \mu \mathrm{l}$ of $0.1 \mathrm{M} \mathrm{HClO}, 1 \mathrm{mM}$ EDTA. After centrifugation of these extracts, the supernatant (the acid extract) was frozen until further use. After thawing, Tris ( $\mathrm{pH} \mathrm{8.6)} \mathrm{was} \mathrm{added} \mathrm{to} 0.67 \mathrm{M}$ and the extract was adsorbed onto an alumina minicolumn to bind the catecholamines. Columns were washed twice with ice-cold water and then eluted with $120 \mu \mathrm{l}$ of $0.4 \mathrm{M} \mathrm{HClO}_{4}, 0.1 \mathrm{mM}$ EDTA. Eluents were then injected onto a reverse-phase C-18 column (Beckman), and catechols were detected by a Bioanalytical Systems model 460 liquid chromatograph with an electrochemical detector. The mobile phase contained $50 \mathrm{mM} \mathrm{NaH} \mathrm{PO}_{4}$ $0.387 \mathrm{~mm}$ sodium octyl sulfate, $0.1 \mathrm{mM}$ EDTA, and 5-7.5\% methanol, and the flow rate was maintained at $1.5 \mathrm{ml} / \mathrm{min}$.

TH assays. TH enzyme activity was analyzed from various organs as described before (Rittenhouse et al., 1988), with slight modifications Excised tissues were homogenized in cold $5 \mathrm{~mm}$ Tris, $0.1 \%$ Triton $\mathrm{X}$ $100, \mathrm{pH} 6.0$. After centrifugation, $10 \mu 1$ of homogenate was used per assay. These assays were performed in $20 \mu \mathrm{l}$ volume, containing a final concentration of $300 \mu \mathrm{M}$ brocresine (an inhibitor of dopa decarboxylase) $80 \mathrm{~mm}$ tyrosine, $40 \mathrm{~mm} \beta$-mercaptoethanol, $3.2 \mathrm{~mm} \mathrm{6-methyl-5,6,7,8-}$ tetrahydropterine, $2 \times 10^{5} \mathrm{U} / \mathrm{ml}$ catalase, and $200 \mathrm{~mm}$ potassium phosphate buffer, $\mathrm{pH} 6.0$, for $6 \mathrm{~min}$ at $37^{\circ} \mathrm{C}$. The reaction was stopped with addition of $1 \mathrm{ml}$ of $0.5 \mathrm{M}$ Tris ( $\mathrm{pH} \mathrm{8.6)}$ containing $0.1 \mathrm{~mm}$ EDTA, and the dopa generated was adsorbed onto alumina columns and washed twice with cold $1 \mathrm{~mm} \mathrm{NaHSO}_{3}, 5 \mathrm{~mm}$ Tris (pH 8.6). The dopa was eluted in $100 \mu \mathrm{l}$ of $150 \mathrm{mM} \mathrm{H}_{3} \mathrm{PO}_{4}, 0.1 \mathrm{mM}$ EDTA from the column and detected by HPLC-ECD as described above. Protein content in the homogenates was determined by the MicroBCA reagent (Pierce).

Deafferentation. A single intranasal dose of $50-100 \mu \mathrm{l}$ of solution was administered to unanesthetized mice ( $\geq 60 \mathrm{~d}$ of age) using a syringe needle that was clipped to approximately $3 \mathrm{~mm}$ in length and filed to a blunt end. Experimental mice received $0.17 \mathrm{M} \mathrm{ZnSO}_{4}$ in $0.15 \mathrm{M} \mathrm{NaCl}$, and control mice received saline. The mice were killed $8 \mathrm{~d}$ following 


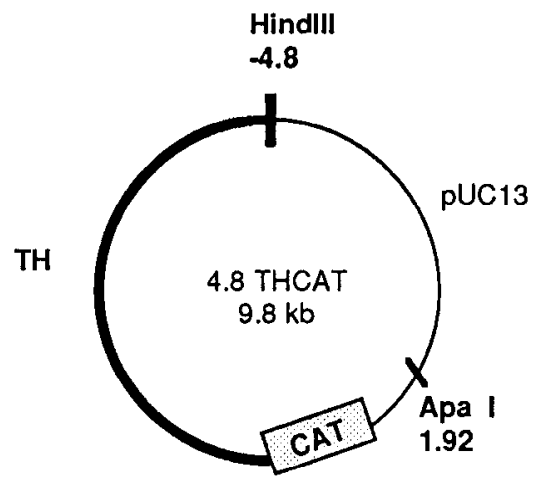

Figure 1. Map of -4.8 TIICAT. The fragment injected into fertilized eggs in order to generate the -4.8 THCAT lines of transgenic mice was the $6.7 \mathrm{~kb}$ HindIII-ApaI fragment that included the CAT gene, the SV40 polyA, and splice sites. The fragment used to generate the -272 THCAT lines of mice was the $2.4 \mathrm{~kb}$ SstI-Apal fragment. The lower part depicts the restriction map of the TH sequences present in the transgene.

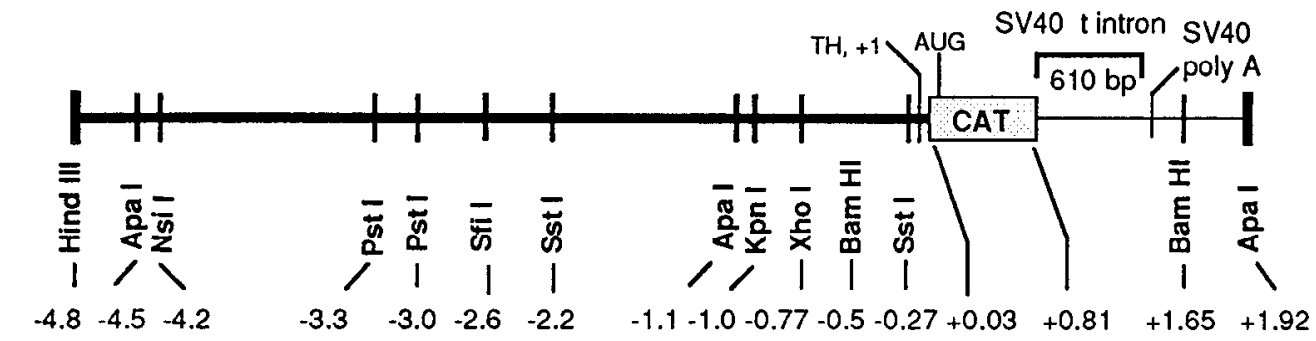

this procedure and single OBs were used for CAT assays and dopamine assays.

\section{Results}

Transgenic analysis

Since cell culture experiments suggested that only 212 nucleotides of the 5 ' flanking sequence of the rat $\mathrm{TH}$ gene were required to confer expression in PC cells, we generated three transgenic lines bearing 272 nucleotides of TH upstream sequence linked to a CAT reporter gene. The founders and two generations of progeny were analyzed for transgene expression. None of the animals expressed CAT activity in any tissue including $\mathrm{TH}$ -

Table 1. Tissue-specific CAT and TH activity in -4.8 THCAT mice

\begin{tabular}{llcc} 
Tissue & $\begin{array}{l}\text { CAT } \\
\text { (\% conversion/ } \\
\text { mg protein) }\end{array}$ & $\begin{array}{l}\text { TH activity } \\
\text { (pmol dopa/mg } \\
\text { protein/min) }\end{array}$ & $\begin{array}{l}\text { CAT/TH } \\
\left(\times 10^{-2}\right)\end{array}$ \\
\hline OB & $26.7 \pm 10$ & $152.3 \pm 53.2$ & 17.5 \\
scg & $8.33 \pm 2.0$ & $1667 \pm 523$ & 0.5 \\
Brain & $0.67 \pm 0.5$ & $38.7 \pm 1.2$ & 1.73 \\
Adrenal & $2.83 \pm 0.5$ & $2915.6 \pm 706$ & 0.1 \\
Liver & ND & NT & \\
Heart & ND & NT & \\
Spleen & ND & NT & \\
Kidney & ND & NT &
\end{tabular}

Extracts for the CAT assays were made from $\geq 60$-d-old animals identified as transgenic by dot blot assays. For all negative tissues and for brain, individual assays were performed on a small fraction of the extract made from a single organ. For the adrenal and scg, four to six organs were pooled for individual assays. For the $\mathrm{OB}$, individual assays were performed on whole bulbs. Numbers are mean CAT activities from these individual assays \pm SEM. Protein assays were performed using the MicroBCA reagent (Pierce). TH assays were performed on transgenic animals and on their nontransgenic littermates, with no significant difference being observed between the two groups. All assays were performed on extracts from single organs (see Materials and Methods). TH assays were not performed on liver, heart, spleen, or kidney, which lack TH activity. Protein assays were performed by the method of Lowry. ND, Not detectable; NT, not tested. positive regions. It is not clear whether this was due to a lack of sequences important for in vivo expression, or whether all three lines were nonexpressors due to integration site effects. We therefore generated transgenic founders carrying a much larger piece of DNA, that is, $4.8 \mathrm{~kb}$ of 5 ' flanking TH sequence. This construct utilized the TH transcriptional start site $(+1)$, the CAT translational initiation site, and the SV40 polyA and splice sites (Fig. 1), such that the CAT gene was under the transcriptional control of the TH $5^{\prime}$ sequences.

Four transgenic founders were obtained that carried an unrearranged transgene determined by Southern blot analysis. Only one line expressed the transgene and was therefore analyzed in this study. The founder was apparently a germline chimera since only 3 out of $24 \mathrm{Fl}$ progeny inherited the transgene. In subsequent generations, the transgene was present in a single copy, which was inherited in a Mendelian manner consistent with an autosomal site of integration. During the course of this study, over 75 transgenic mice from eight generations were analyzed. In all cases, expression of the transgene was detected with no extinction in any of the progeny. In addition, transgene expression, as quantitated by CAT activity, was dose dependent, with homozygotes showing a twofold higher level of CAT expression than heterozygotes (data not shown). The animals reported here were all heterozygous for the CAT transgene.

\section{Tissue-specific expression}

Tissue extracts were prepared from TH-positive tissues: whole brain excluding the OB (henceforth referred to as "brain"), the $\mathrm{OB}$, a sympathetic ganglion (the scg), and the adrenal glands, as well as from TH-negative tissues like the heart, liver, kidney, and spleen. CAT activity was detected in all tissues in which TH cells are found, although it was very low in whole brain, due to the dilution of the CAT-expressing cells with nonexpressing cell types (Table 1). No activity was seen in any THnegative tissue.

To assess how the activity of the CAT reporter compared to 
endogenous $\mathrm{TH}$ activity, $\mathrm{TH}$ assays were performed on the all TH-positive tissues (Table 1, column 2). Since TH assays were performed in vitro under fully activating conditions, activity should reflect $\mathrm{TH}$ protein levels. When CAT levels were normalized to endogenous TH enzyme activity, the adrenal showed lower CAT activity than would be predicted based on its endogenous TH enzyme activity (Table 1 , column 3 ). This was also truc for the scg, although to a lesser extent. In addition, $\mathrm{TH}$ activities from brain, adrenal, $\mathrm{scg}$, and $\mathrm{OB}$ of nontransgenic animals were not significantly different from those of transgenic animals, suggesting that transgene expression did not alter the expression of endogenous TH (data not shown).

These data demonstrate that $4.8 \mathrm{~kb}$ of $5^{\prime}$ flanking TH sequence is sufficient to direct appropriate tissue-specific expression of CAT, but at a lower level in the periphery than would be predicted by the endogenous TH activity.

\section{CAT expression in various brain regions}

To determine if the expression of CAT within the brain was restricted to the regions known to contain TH-positive cells, we assayed CAT activity in dissected brain regions. Since CAT is a bacterial protein and presumably lacks axonal transport signals, most of the protein should remain in the cell bodies of TH-expressing neurons. Therefore, we assayed CAT activity in extracts from regions containing TH-positive cell bodies such as the ventral midbrain (containing the ventral tegmental area and the substantia nigra; SN-VTA), pons-medulla (containing the locus coeruleus and the lateral tegmental area), and hypothalamus. Areas that have no TH-positive cell bodies but receive catecholaminergic projections were also assayed. These included the hippocannus, striatum, cerebellum, anterior olfactory nucleus (AON), and cortex.

All areas containing TH-positive nuclei showed significant levels of CAT activity (Fig. 2). A much lower level of activity was observed in some areas like the striatum and the AON, which contain no TH-positive cell bodies but are heavily innervated by projections from TH-positive cells. Sparsely innervated regions such as the cortex and hippocampus showed levels of activity that were statistically background. It is likely that a small amount of CAT protein is found in the axoplasm in areas innervated by TH cells resulting in the low activity observed in heavily innervated regions. However, the possibility that there are a small number of cells in these regions that are ectopically expressing CAT cannot be ruled out, since CAT cannot be localized by immunohistochemical methods (Wuenscell et al., 1990; Banerjee and Chikaraishi, unpublished observations).

\section{Developmental regulation of $C A T$ in the $O B$}

To determine whether $4.8 \mathrm{~kb}$ of $5^{\prime}$ flanking rat TH DNA could direct accurate developmental expression, we assayed for CAT activity in OBs of transgenic animals at various times after birth. Unlike most other TH-positive neurons, the onset of $\mathrm{TH}$ expression in the $\mathrm{OB}$ is almost entirely postnatal. TH-positive neurons of most catecholaminergic groups in the rat brain are present by $\mathrm{E} 14.5$; in contrast, $\mathrm{TH}$-immunoreactive cells first appear in the $\mathrm{OB}$ at E2 1 , shortly before parturition, and continue to increase until 2 months after birth (Specht et al., 1981a,b; McLean and Shipley, 1988).

Because of the robust CAT activity in the $\mathrm{OB}$, we were able to quantitate CAT levels from a single bulb, using the other bulb for TH activity. As shown in Figure $3 A$, CAT expression

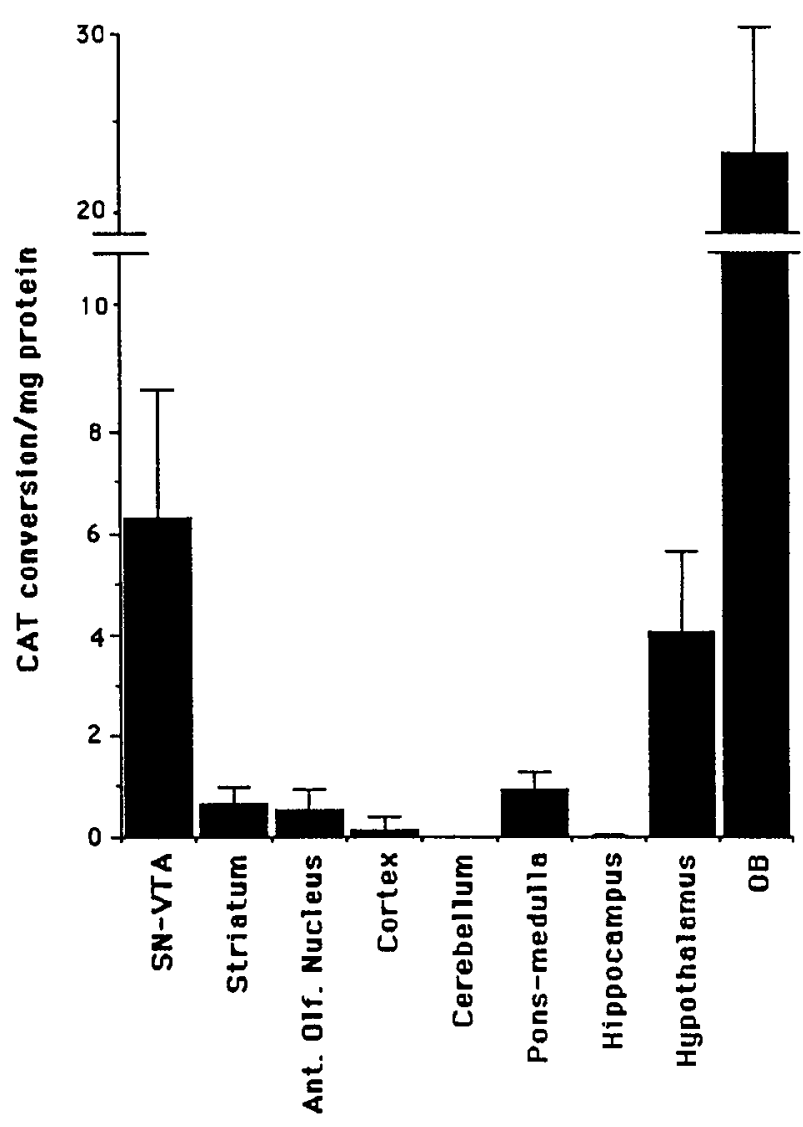

Figure 2. Spccificity of CAT cxpression in disscetcd brain regions. CAT assays were performed on extracts made from dissected regions from transgenic mice $>60 \mathrm{~d}$ old as identified previously by dot blots. Up to $200 \mu \mathrm{g}$ of protein was used for each assay. Each bar represents a mean \pm SEM of CAT assays from four transgenic animals.

increased steadily until day 21 , after which there was no further increase. The rise in CAT activity coincided closely with that of endogenous $\mathrm{TH}$, which also increased until postnatal day 21 (Fig. $3 B$ ). The large SDs observed at each time point are probably the result of the mixed genetic background of individual progeny, caused by breeding of the transgenic animals to B6D2 hybrids at every generation. It has previously been shown that significant strain-specific differences exist in the levels of $\mathrm{TH}$ in the brain (Reis et al., 1978). Nevertheless, the developmental pattern of CAT expression parallels that of endogenous $\mathrm{TH}$ activity, suggesting that $4.8 \mathrm{~kb}$ of upstream region of $\mathrm{TH}$ sequences directs appropriate developmental regulation in the OB.

\section{Transsynaptic regulation in the $O B$}

To determine whether our construct could mediate responsiveness to an authentic transsynaptic stimulus, we examined the dependence of CAT on afferent innervation in the OB. This paradigm was studied for three reasons. First, because robust expression of CAT was observed in the $\mathrm{OB}$, transgene expression could be assayed in single animals. Second, the $O B$ is a wellstudied model for the transsynaptic rcgulation of TH. Finally, these studies would allow a functional demonstration of CAT expression in the appropriate subset of cells in the OB, since deafferentation specifically affects the TH-positive cells in the OB.

$\mathrm{TH}$ in the $\mathrm{OB}$ is expressed in the periglomerular and external tufted cells (together known as the juxtaglomerular neurons), 

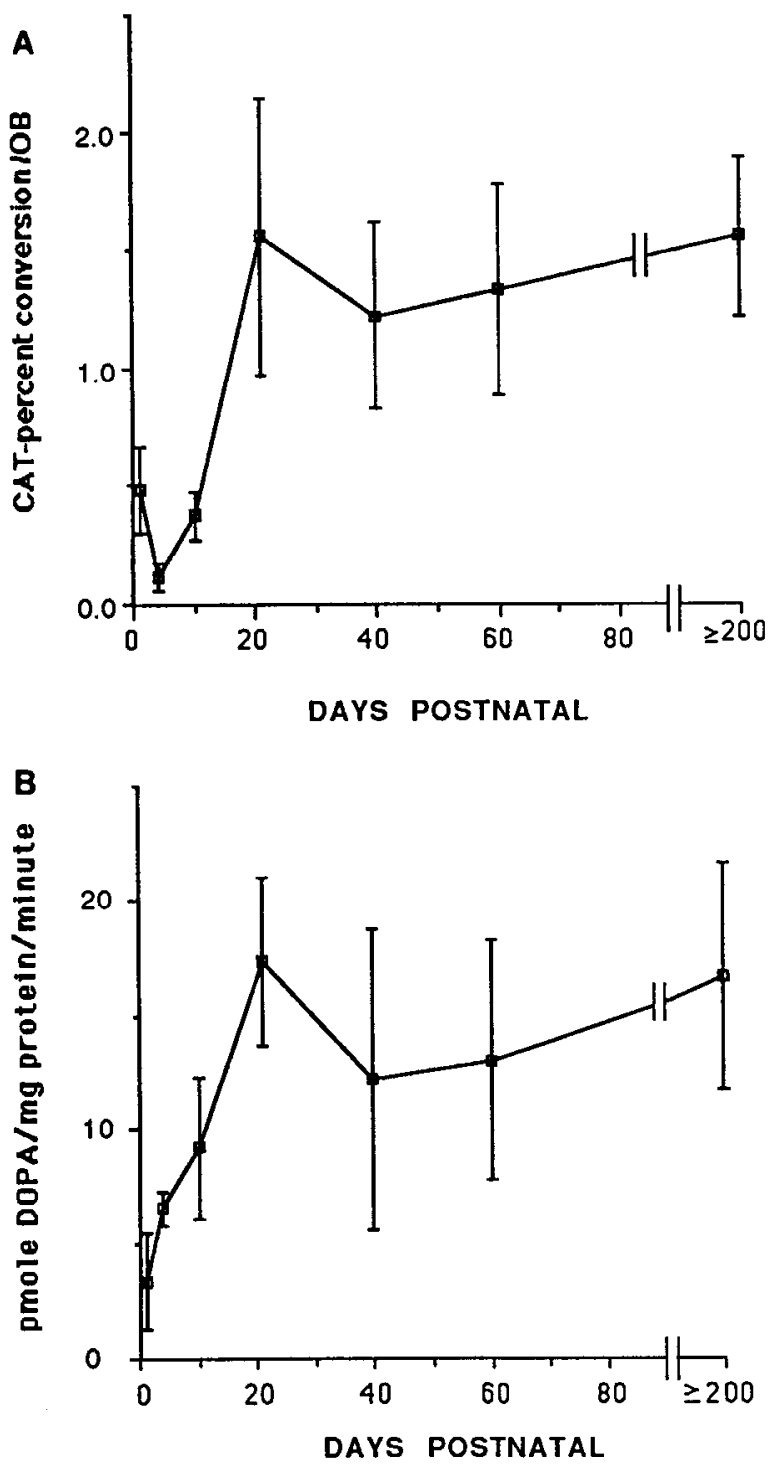

Figure 3. $\mathrm{CAT}$ and $\mathrm{TH}$ development in transgenic and nontransgenic mice. $A$, Developmental expression of CAT in the OB of transgenic mice. CAT assays were performed on single bulbs of transgenic mice previously identified by dot blots, on postnatal days $1,4,10,21,40$, 60 , and $>200$. Each point represents mean \pm SEM assays on four or five mice. ANOVA analysis of the data revealed that CAT levels at postnatal day 21 were significantly different from those at day 1 , day 4 , and day 10 , but not at day 40 , day 60 , or day $>200(p<0.05)$. $B$, Developmental expression of TH in the OB of transgenic mice and their nontransgenic littermates. TH assays were performed on the remaining OB of the same animals used for CAT activity at postnatal days 1,4 , $10,21,40,60$, and $>200$. Two or three transgenic mice and two or three nontransgenic littermates were used for each time point. Since no significant difference was observed, the data were pooled. Each point represents mean \pm SEM of assays on four to six mice. ANOVA analysis of the data revealed that $\mathrm{TH}$ levels at postnatal day 21 were significantly different from those at day 1 , day 4 , and day 10 , but not at day 40 , day 60 , or day $>200(p<0.05)$.

which receive afferents from olfactory neurons whose cell bodies reside in the nasal epithelium. Expression of $\mathrm{TH}$ in these $\mathrm{OB}$ neurons requires that these inputs be intact (Baker et al., 1983). If destroyed, TH activity (Baker et al., 1988), immunoreactivity (Baker et al., 1983, 1984), and RNA (Ehrlich et al., 1990) are severely reduced. Although deafferentation induces loss of TH, the juxtaglomerular neurons do not die, and can be detected by
Table 2. Regulation of CAT activity in response to deafferentation

\begin{tabular}{lcll} 
Animals & $n$ & $\begin{array}{l}\text { CAT activity } \\
(\% \text { conver- } \\
\text { sion/bulb } \\
\pm \text { SD) }\end{array}$ & $\begin{array}{l}\text { Dopamine } \\
\text { (pmol/bulb } \pm \\
\text { SD) }\end{array}$ \\
\hline Transgenic, untreated & 6 & $1.4 \pm 0.34$ & $\mathrm{NT}$ \\
Transgenic, deafferented & 8 & $0.56 \pm 0.17$ & $1.5 \pm 0.41$ \\
Transgenic, saline treated & 8 & $1.37 \pm 0.5$ & $4.94 \pm 1.78$ \\
Nontransgenic, saline treated & 4 & ND & $5.36 \pm 1.38$
\end{tabular}

Animals that were $\geq 60$ d old were subjected to an intranasal lavage with $50-100$ $\mu \mathrm{l}$ of $0.17 \mathrm{M} \mathrm{ZnSO}_{4}$ in $0.15 \mathrm{M} \mathrm{NaCl}$ or with saline alone. Both sets were killed 8 $\mathrm{d}$ following treatment. CAT activity was assaycd from the left OB and dopamine assays were performed on the right bulb of each animal. The number of animals used in each category is denoted by $n$. ND, Not detectable; NT, not tested.

the continued presence of dopa decarboxylase (Baker et al., 1984).

Because TH is specifically lost after destruction of direct synaptic inputs to the juxtaglomerular neurons, it is likely that ectopically expressed CAT, that is, in nonjuxtaglomerular neurons, would not be reduced by deafferentation. It was therefore expected that CAT would be transsynaptically regulated only if expressed in the TH-expressing cells of the bulb and if our construct contained sequences capable of mediating this effect. We therefore assayed the loss of CAT activity in response to afferent denervation.

Deafferentation can be experimentally induced by $\mathrm{ZnSO}_{4}$ lavage of the nasal epithelium, which destroys olfactory receptor neurons (Harding et al., 1978; Cancalon, 1982). Under certain conditions, $\mathrm{ZnSO}_{4}$-induced deafferentation does not result in permanent loss of olfactory epithelial neurons (Harding et al., 1977; Cancalon, 1982) such that regeneration of the olfactory neurons occurs over time. An $8 \mathrm{~d}$ time point was chosen in our experiments because previous work (M. Schwartz-Levey, unpublished observations) has shown that at $8 \mathrm{~d}$, no regeneration should have ensued. Transgenic animals were deafferented by a bilateral intranasal irrigation with $0.17 \mathrm{M} \mathrm{ZnSO}_{4}$. Eight days later, one $\mathrm{OB}$ from each animal was assayed for CAT expression, and endogenous dopamine was quantitated in the other bulb. Previous work had shown that $\mathrm{ZnSO}_{4}$ deafferentation reduces dopamine to $15-30 \%$ of control levels (Nadi et al., 1981; Kawano and Margolis, 1982).

Control saline-treated animals had CAT expression comparable to untreated transgenic mice, establishing that intranasal irrigation had no effect on CAT activity (Table 2). Dopamine levels in these animals were also comparable to levels in salinetreated wild-type littermates of the transgenic animals. In contrast, the dopamine levels in the $\mathrm{ZnSO}_{4}$-treated transgenic mice were about $30 \%$ of those from the saline-treated animals after $8 \mathrm{~d}$, demonstrating that the deafferentation was successful. CAT activity in the same animals dropped to $41 \%$ of levels in control animals (saline-treated and untreated transgenic animals), similar to the reported decrease in TH enzyme activity assayed 7 $\mathrm{d}$ after lavage (Nadi et al., 1981). Therefore, the reduction in CAT expression in these animals shows that the transgene is regulated by afferent input, arguing that CAT expression is cell specific, and the TH DNA elements in the transgene are capable of mediating the transsynaptic effect.

\section{Discussion}

We generated four lines of transgenic mice bearing $4.8 \mathrm{~kb}$ of $5^{\prime}$ TH flanking sequences linked to CAT. Only one line expressed 
the transgene in any tissue and was analyzed further. Presumably, the transgene integrated in a region of DNA that did not allow transcription in the other three lines, although we cannot rule out that posttranscriptional mechanisms may be responsible for the lack of CAT enzyme activity. Likewise, it is possible that the correct expression we detect in the expressing line is due to an integration site effect, specific for that particular lineage; however, given the number of different tissues assayed, the regional specificity within the brain and the appropriate developmental and transsynaptic regulation in the $\mathrm{OB}$, it seems unlikely that the expression we observe is due to a random, fortuitous event.

\section{$4.8 \mathrm{~kb}$ of $5^{\prime} \mathrm{TH}$ sequences is sufficient for tissue-specific expression}

The $4.8 \mathrm{~kb}$ of upstream TH sequence used in these studies targets expression of CAT exclusively to tissues containing TH-expressing cells: we observed expression in the adrenal, scg, and regions of the brain that contain TH-positive neurons. CAT activity was undetectable in all of the other tissues assayed including liver, heart, spleen, and kidney. Areas of the brain that are innervated by TH neurons, but do not contain TH cell bodies, contained very low levels of CAT activity, perhaps due to small amounts of transported CAT protein.

The total amount of CAT per region, calculated from the amount of protein recovered from each region and the specific activities in Figure 2, roughly paralleled the number of $\mathrm{TH}$ neurons in each area. Although exact counts of TH neurons are not available in the mouse, if mice and rats have the same proportion of TII neurons in various regions, the OB has the largest number of TH neurons [150,00 per bulb in the rat (McLean and Shipley, 1988)] and by far the greatest CAT activity. The next largest group of TH neurons, the SN-VTA (Bjorklund and Lindvall, 1984), has about one-quarter the number of TH neurons in the OB and about one-quarter as much CAT. Likewise, the pons-medulla has one-quarter as many cells as the $\mathrm{SN}$ VTA and proportionately less CAT. The hypothalamus has the fewest TH neurons but has disproportionately high CAT activity, with levels between that of the SN-VTA and the ponsmedulla. Part of this activity may be due to axonally transported CAT, since the hypothalamus is heavily innervated by THpositive neurons. Nevertheless, CAT expression in dissected brain regions is specific to areas bearing $\mathrm{TH}$ cell bodies, and largely reflects the number of $\mathrm{TH}$ cells in each region.

When compared to endogenous $\mathrm{TH}$ activity in a given region, CAT expression was higher in the CNS (OB and brain) than in the PNS (adrenal or scg). This suggests that the TH regulatory sequences used in this study preferentially target expression to the CNS, although CAT activity is clearly present in the adrenal and the scg. These data are consistent with a recent study (Kaneda et al., 1991) in which the entire human TH gene (including $2.5 \mathrm{~kb}$ of upstream TH sequences, the entire coding region with introns, and $0.5 \mathrm{~kb}$ of downstream sequences) directed a 10 fold lower expression of the human TH transgene in the adrenal as compared to the brain. Although our construct includes an extra $2.3 \mathrm{~kb}$ of $5^{\prime}$ DNA (from -2.5 to $-4.8 \mathrm{~kb}$ ), there is still a 20-50-fold higher CAT expression in the CNS compared to adrenal. Therefore, elements required for full PNS expression may still be lacking in the -4.8 construct. Since our study measured TH and CAT enzyme activities, the observed disparity could reflect post-transcriptional events, although the study by
Kaneda et al. (1991) demonstrated a similar disparity in the RNA expression.

Our results differ from previous studies (Kaneda et al., 1991; Morgan and Sharp, 1991; Suri and Chikaraishi, 1991) by demonstrating CAT expression in the $\mathrm{OB}$ and in the sympathetic ganglia $(\mathrm{scg})$. Furthermore, our data on dissected brain regions reflects accurate expression of CAT in all the appropriate brain regions; in contrast, previous studies using up to $3.5 \mathrm{~kb}$ of upstream sequences from the mouse TH gene and the entire coding region including introns as well as $0.5 \mathrm{~kb}$ of downstream region from the human gene demonstrated ectopic expression in the brain. Although some regions were correctly targeted, inappropriate reporter expression occurred in a variety of CNS loci. Taken together, these data imply that elements between -3.5 and $-4.8 \mathrm{~kb}$ may be important for restricting ectopic CNS expression. Studies in our laboratory using $2.8 \mathrm{~kb}$ of the $5^{\prime}$ flanking region of the rat $\mathrm{TH}$ gene resulted in a similar mixed pattern of appropriate and ectopic expression (Suri and Chikaraishi, 1991). This indicates that at least in the rat gene, elements that lie between -2.8 and $-4.8 \mathrm{~kb}$ are important for allowing full expression in all $\mathrm{TH}$-positive areas, and suppressing ectopic expression. These data imply that multiple elements spread over as much as $4.8 \mathrm{~kb}$ of flanking DNA may mediate activation and repression to generate the final pattern of $\mathrm{TH}$ expression. Although our data implicate a long 5 ' flanking region for correct cell specificity, it does suggest that coding, intronic, and $3^{\prime}$ flanking sequences are not necessary. Unfortunately, these studies cannot address the contribution of other important sequences that lie closer to the transcription start site, which work in conjunction with more distal elements.

Although the regulatory regions of only a few neuronal genes have been studied in transgenic mice, two genes, phenylethanolamine $N$-methyltransferase (Baetge et al., 1988) and neuronspecific enolase (Forss-Petter et al., 1990), have regulatory elements capable of directing correct reporter expression within $2 \mathrm{~kb}$ of their RNA initiation sites. Appropriate expression has been demonstrated for several other neuronal genes using 4-5 $\mathrm{kb}$ of upstream information (olfactory marker protein, Danciger et al., 1989; amyloid precursor protein, Wirak et al., 1991; SCG10, Wuenschell et al., 1990); however, since deletional analysis has not been performed, it is unclear what minimum length is required for correct specificity. Recently, it was shown that $5.8 \mathrm{~kb}$ of the $5^{\prime}$ region of the dopamine $\beta$-hydroxylase (DBH) gene is sufficient to target reporter expression to the appropriate areas (Mercer et al., 1991). DBH is the third enzyme of the catecholamine neurotransmitter pathway.

\section{$C A T$ expression in the $O B$ parallels endogenous $T H$ expression both in response to transsynaptic stimulation, and during development}

We show that $4.8 \mathrm{~kb}$ of TH $5^{\prime}$ flanking DNA directed accurate developmental regulation of CAT in the OB. The postnatal rise in endogenous TH activity was directly paralleled by a postnatal increase in CAT expression. Both activities increased until 3 weeks after birth. This plateau at 3 weeks is in contrast with the results obtained by McLean and Shipley (1988) in the rat, using immunohistochemical methods in which they demonstrated that the number of TH-immunoreactive cells increase linearly until 2 months after birth. However, a more prolonged time course for the development of TH in the rat as compared to the mouse has been demonstrated in the scg (Black et al., 1974); perhaps 
the same occurs in the $\mathrm{OB}$. Nevertheless, in the mouse $\mathrm{OB}$, the CAT reporter activity reflected endogenous TH activity.

Unlike most other TH cell groups, OB neurons need to complete their migration and receive their afferent innervation before they express $\mathrm{TH}$, implying that developmental $\mathrm{TH}$ expression is a manifestation of transsynaptic regulation. However, it has recently been suggested that the presence of intact afferent connections may not be sufficient for maintaining $\mathrm{TH}$ in the $\mathrm{OB}$; rather, the maintenance of $\mathrm{TH}$ requires input electrical activity from afferent fibers. If the $\mathrm{OB}$ is allowed to develop normally, but odorant access is occluded by naris cauterization, there is a decrease in dopamine content (Brunjes et al., 1985), TH immunoreactivity, TH enzyme activity (Kosaka et al., 1987), and TH message (Stone et al., 1990), although the result is less dramatic than that resulting from chemical or surgical deafferentation. This indicates that development of $\mathrm{TH}$ expression in the $O B$ is activity dependent. Thus, our construct contains sequences to mediate the developmental induction of $\mathrm{TH}$, which occurs in an activity-dependent manner.

To demonstrate directly that CAT expression is transsynaptically regulated in a manner similar to the endogenous TH in the $\mathrm{OB}$, we chemically deafferented the $\mathrm{OB} . \mathrm{ZnSO}_{4}$-induced necrosis of the olfactory epithelial neurons removes afferent innervation to the dopaminergic neurons of the $\mathrm{OB}$. This results in a progressive loss of TH expression such that $8 \mathrm{~d}$ after $\mathrm{ZnSO}_{4}$ treatment TH activity is about $40 \%$ of normal levels, which is also reflected in dopamine levels (Nadi et al., 1981; present results). After about 21 d, TH RNA (Ehrlich et al., 1990) and protein levels (Baker et al., 1983) are less than $10 \%$ of normal levels.

In $\mathrm{ZnSO}_{4}$-treated transgenic mice, CAT levels dropped to about $40 \%$ to those of saline-treated controls, and dopamine levels fell to about $30 \%$ of control levels after $8 \mathrm{~d}$, which are comparable to levels found by others for TH and dopamine, respectively (Nadi et al., 1981; Kawano and Margolis, 1982).

Transneuronal regulation is a selective process; TH is reduced, but other neurotransmitter enzymes like glutamic acid decarboxylase (Kosaka et al., 1987) and amino acid (dopa) decarboxylase (Stone et al., 1990), which colocalize with TH, are not. In addition, a variety of other molecules present in the $\mathrm{OB}$, like PEP 19, cyclic nucleotides, ChAT, and neurotransmitter uptake systems, are not altered by deafferentation (Margolis et al., 1974; Ehrlich et al., 1990). PEP 19 is present in the granule cells of the $\mathrm{OB}$ that receive no input from the olfactory neurons. Thus, the specificity of transsynaptic TH regulation presumably depends partly on the restricted afferentation of the olfactory neurons onto the TH-expressing glomerular neurons, and partly on DNA elements in the regulatory region of the gene that are capable of mediating the effect. We hypothesize that the accurate transsynaptic regulation of CAT that we observe is consistent with CAT expression in the appropriate dopaminergic neurons. It also indicates that our construct contains sequences that mediate the transsynaptic regulation of $\mathrm{TH}$.

Thus, the same cues that are required to induce initial $\mathrm{TH}$ expression during development may also maintain $\mathrm{TH}$ expression in the adult. In the $\mathrm{OB}$, these cues are activated by input electrical activity. The transcriptional activation of several genes have been shown to be mediated by depolarizing stimuli. In two well-studied cases, the human proenkephalin gene (Nguyen et al., 1990) and the immediate-early gene c-fos (Sheng et al., 1990), a cAMP response element (CRE) has been shown to mediate depolarization-induced transcription. The TH gene has such an element at -45 , although further experiments will be necessary to determine if the CRE mediates transsynaptic induction of TH.

In conclusion, we have generated a line of transgenic mice that express a CAT reporter driven by $4.8 \mathrm{~kb}$ of $5^{\prime} \mathrm{TH}$ sequences, in a manner reflecting endogenous $\mathrm{TH}$ expression in all tissues tested, including discrete brain regions. Furthermore, in the $\mathrm{OB}$, there is accurate transsynaptic and developmental expression of CAT, suggesting that $4.8 \mathrm{~kb}$ is sufficient for mediating these events.

\section{References}

Aloe L, Levi-Montalcini R (1979) Nerve-growth factor-induced transformation of immature chromaffin cells in vivo into sympathetic neurons: effect of antiserum to nerve growth factor. Proc Natl Acad Sci USA 76:1246-1250.

Anderson DJ, Axel R (1986) A bipotential neuroendocrine precursor whose choice of cell fate is determined by NGF and glucocorticoids. Cell 47:1079-1090.

Anderson DJ, Carnahan JF, Michelsohn A, Patterson PH (1991) Antibody markers identify a common progenitor to sympathetic neurons and chromaffin cells in vivo and reveal the timing of commitment to neuronal differentiation in the sympathoadrenal lineage. J Neurosci 11:3507-3519.

Baetge EE, Behringer RR, Messing A, Brinster RL, Palmiter RD (1988) Transgenic mice express the human phenylethanolamine $N$-methyltransferase gene in adrenal medulla and retina. Proc Natl Acad Sci USA 85:3648-3652.

Baker H, Kawano T, Margolis FL, Joh TH (1983) Transneuronal regulation of tyrosine hydroxylase expression in the olfactory bulb of mouse and rat. J Neurosci 3:69-78.

Baker H, Kawano T, Albert V, Joh TH, Reis DJ, Margolis FI, (1984) Olfactory bulb dopamine neurons survive deafferentation-induced loss of tyrosine hydroxylase. Neuroscience 11:605-615.

Baker H, Towle AC, Margolis FL (1988) Differential afferent regulation of dopaminergic and GABAergic neurons in the mouse main olfactory bulb. Brain Res 450:69-80.

Bjorklund A, Lindvall O (1984) Dopamine-containing systems in the CNS. In: Handbook of chemical neuroanatomy, Vol 2 (Bjorklund A, Hokfelt T, eds), pp 55-122. Amsterdam: Elsevier.

Black IB, Joh TY, Reis DJ (1974) Accumulation of tyrosine hydroxylase molecules during growth and development of the superior cervical ganglion. Brain Res 75:133-144.

Blackwell TK, Weintraub H (1990) Differences and similarities in DNA-binding preferences of MyoD and E2A protein complexes revealed by binding site selection. Science 250:1104-1110.

Brunjes PC, Smith-Crafts LK, McCarty R (1985) Unilateral odor deprivation: effects on the development of olfactory bulb catecholamincs and bchavior. Dev Brain Res 22:1-6.

Cambi F, Fung B, Chikaraishi D (1989) 5' flanking DNA sequences direct cell-specific expression of rat tyrosine hydroxylase. J Neurochem 53:1656-1659.

Cancalon P (1982) Degeneration and regeneration of olfactory cells induced by $\mathrm{ZnSO}_{4}$ and other chemicals. Tissue Cell 14:717-733.

Curran T, Franza R (1988) Fos-Jun: the AP-1 connection. Cell 55: 395-397.

Danciger E, Mettling C, Vidal M, Morris R, Margolis F (1989) Olfactory marker protein gene: its structure and olfactory neuron-specific expression in transgenic mice. Proc Natl Acad Sci USA 86:85658569.

Doupe AJ, Landis SC, Patterson PH (1985) Environmental influences in the development of neural crest derivatives: glucocorticoids, growth factors, and chromaffin cell plasticity. J Ncurosci 5:2119-2142.

Ehrlich ME, Grillo M, Joh TH, Margolis FL, Baker H (1990) Transneuronal regulation of neuronal specific gene expression in the mouse olfactory bulb. Mol Brain Res 7:115-122.

Forss-Petter S, Danielson PE, Catsicas S, Battenberg E, Price J, Nerenberg M, Sutcliffe JG (1990) Transgenic mice expressing $\beta$-galactosidase in mature neurons under neuron-specific enolase promoter control. Neuron 5:187-197.

Fung B, Yoon SO, Chikaraishi DM (1992) Sequences that direct rat tyrosine hydroxylase expression. J Neurochem 58:2044-2052.

Harding J, Graziadei PPC, Monti Graziadei GA, Margolis FL (1977) 
Denervation in the primary olfactory pathway of mice. IV. Biochemical and morphological evidence for neuronal replacement following nerve section. Brain Res 132:11-28.

Harding JW, Getchell TV, Margolis FL (1978) Denervation of the primary olfactory pathway in mice. V. Long-term effect of intranasal $\mathrm{ZnSO}_{4}$ irrigation on behavior biochemistry and morphology. Brain Res 140:271-285.

Kaneda N, Sasaoka T, Kobayashi K, Kiuchi K, Nagatsu I, Kurosawa Y, Fujita K, Yokoyama M, Nomura T, Katsuki M, Nagatsu T (1991) Tissue-specific and high level expression of the tyrosine hydroxylase gene in transgenic mice. Neuron 6:583-594.

Kawano T, Margolis FL (1982) Transsynaptic regulation of olfactory bulb catecholamines in mice and rats. J Neurochem 39:342-348.

Kosaka T, Kosaka K, Hama K, Wu J-Y, Nagatsu I (1987) Differential effect of functional olfactory deprivation on the GABAcrgic and catecholaminergic traits in the rat main olfactory bulb. Brain Res 413: 197-203.

Margolis FL, Roberts N, Ferreiro D, Feldman J (1974) Denervation in the primary olfactory pathway of mice: biochemical and morphological effects. Brain Res 81:469-483.

McLean JH, Shipley MT (1988) Postmitotic, postmigrational expression of tyrosine hydroxylase in the olfactory bulb dopaminergic neurons. J Neurosci 8:3658-3669.

Mercer EH, Hoyle GW, Kapur RP, Brinster RL, Palmiter RD (1991) The dopamine $\beta$-hydroxylase gene promoter directs expression of $E$. coli lac $\mathrm{Z}$ to sympathetic and other neurons in adult transgenic mice. Neuron 7:703-716.

Mercola M, Goverman J, Mirell C, Calame K (1985) Immunoglobulin heavy-chain enhancer requircs onc or morc tissuc-specific factors. Science 227:266-269.

Morgan WW, Sharp ZD (1991) In vivo tissue-specific expression of a chimaeric construct containing $3.5 \mathrm{~kb}$ of the $5^{\prime}$ flanking DNA for the mouse tyrosine hydroxylase gene. Soc Neurosci Abstr 17:538.

Murre C, McCaw PS, Baltimore D (1989) A new DNA binding and dimerization motif in immunoglobulin enhancer binding, daughterless, Myo $D$ and $m y c$ proteins. Cell 56:777-783.

Nadi NS, Head R, Grillo M, Hempstead I, Grannot-Reisfeld N, Margolis FL (1981) Chemical deafferentation of the olfactory bulb: plasticity of the levels of tyrosine hydroxylase, dopamine and norepinephrine. Brain Res 213:365-377.

Naujoks KW, Korsching S, Rohrer H, Thoenen H (1982) Nerve growth factor-mediated induction of tyrosine hydroxylase and neurite out- growth in cultures of bovine adrenal chromaffin cells: dependence on developmental stage. Dev Biol 92:365-379.

Nguyen TV, Kobierski L, Comb M, Hyman S (1990) The effect of depolarization on expression of the human proenkephalin gene is synergistic with cAMP and dependent upon a cAMP-inducible enhancer. J Neurosci 10:2825-2833.

Reis DJ, Baker H, Fink JS, Joh TJ (1978) A genetic control of the number of central dopamine neurons in relationship to brain organization, drug responses, and behavior. In: Catecholamines: basic and clinical frontiers, Vol 1 (Usdin E, Kopin IJ, Barchas J, eds), pp 2333. New York: Permagon.

Rittenhouse AR, Schwarzschild MA, Zigmond RE (1988) Both synaptic and antidromic stimulation of neurons in the rat superior cervical ganglion acutely increase tyrosine hydroxylase activity. Neuroscience 25:207-215.

Sheng M, McFadden G, Greenberg ME (1990) Membrane depolarization and calcium induce c-fos transcription via phosphorylation of transcription factor CREB. Neuron 4:571-582.

Specht LA, Pickel VM, Joh TH, Reis DJ (1981a) Light-microscopic immunocytochemical localization of tyrosine hydroxylase in prenatal rat brain. I. Early ontogeny. J Comp Neurol 199:233-253.

Specht LA, Pickel VM, Joh TH, Reis DJ (1981b) Light-microscopic immunocytochemical localization of tyrosine hydroxylase in prenatal rat brain. II. Late ontogeny. J Comp Neurol 199:255-276.

Stone DM, Wessel T, Joh TH, Baker H (1990) Decrease in tyrosine hydroxylase, but not aromatic L-amino acid decarboxylase, messenger RNA in rat olfactory bulb following neonatal unilateral odor deprivation. Mol Brain Res 8:291-300.

Suri C, Chikaraishi DM (1991) Ncw catecholaminergic brain and adrenal cell lines from transgenic mice. Soc Neurosci Abstr 17:528.

Wirak DO, Bayney R, Kundel CA, Lee A, Scangos GA, Trapp BD, Unterbeck AJ (1991) Regulatory region of human amyloid precursor protein (APP) gene promotes neuron-specific gene expression in the CNS of transgenic mice. EMBO J 10:289-296.

Wuenschell CW, Mori N, Anderson DJ (1990) Analysis of SCG10 gene expression in transgenic mice reveals that neural specificity is achieved through selective derepression. Neuron 4:595-602.

Yoon SO, Chikaraishi DM (1992) Tissue-specific transcription of the rat tyrosine hydroxylase gene requires synergy between an AP-1 motif and an overlapping E-box containing dyad. Neuron 9:55-67. 